\title{
Effects of addition of mola at different densities on production of giant freshwater prawn
}

\author{
R. Pervin, M. A. Wahab, K. Fatema and M. S. R. Khan \\ Department of Fisheries Management, Bangladesh Agricultural University, Mymensingh-2202, Bangladesh \\ E-mail: rubaiya_parveen@yahoo.com
}

\begin{abstract}
The effects of mola (Amblypharyngodon mola) at different densities in polyculture with freshwater prawn (Macrobrachium rosenbergii) were investigated at the Fisheries Field Laboratory, Bangladesh Agricultural University, Mymensingh. The experiment had three treatments, viz. prawn +1 mola $\mathrm{m}^{-2}$, prawn $+1.5 \mathrm{mola} \mathrm{m}^{-2}$ and prawn +2 mola $\mathrm{m}^{-2}$ and were treated as $\mathrm{T}_{1}, \mathrm{~T}_{2}$, and $\mathrm{T}_{3}$, respectively with three replications in each. Prawn stocking density was same $\left(3\right.$ juvenile $\mathrm{m}^{-2}$ ) in all treatments. Feeds were applied twice daily for prawn. Assuming $80 \%$ survival, feeding rates were gradually reduced to $10-5 \%$ of body weight from the beginning to the last month. Water quality parameters (except transparency, chlorophyll-a) did not vary significantly $(\mathrm{P}>0.05)$. Weight gain, SGR (\% body weight), gross and net production of prawn were not significantly different $(P>0.05)$. Higher total production was recorded in $T_{3}(574.61$ $\left.\pm 39.58 \mathrm{~kg} \mathrm{ha}^{-1}\right)$ followed by $T_{1}\left(531.65 \pm 42.40 \mathrm{~kg} \mathrm{ha}^{-1}\right)$ and $T_{2}\left(514.75 \pm 77.91 \mathrm{~kg} \mathrm{ha}^{-1}\right)$. It was found that addition of mola at different densities had no effects on survival and production performance of prawn. Therefore, nutrient-dense mola may be stocked as an additional species with freshwater prawn. It might be concluded that treatment $T_{3}$ was better proposition for prawn-mola polyculture.
\end{abstract}

Keywords: Freshwater Prawn, Mola, Nutrient-dense, Polyculture

\section{Introduction}

In Bangladesh, fisheries sector is providing 58\% animal protein (DoF, 2011), but a large proportion of the population in Bangladesh suffers from malnutrition and about 30,000 children become night blind each year from vitamin A deficiency. Some of small indigenous fish species such as mola (Amblypharyngodon mola) and dhela (Osteobrama cotio cotio) contain more available vitamin-A than any other freshwater fish (Thilsted et al., 1997). Fisheries sector earning about 340.45 million taka which contributes about $2.7 \%$ in the country's economy of which freshwater prawn (Macrobrachium rosenbergii) is one of the most important species (DoF, 2011). Prawn is cultured in around 50,000 hectare and gradually spreading towards the north and southeast region of the country as well. While this omnivore species is cultured as a single bottom feeding shellfish, the entire column of water remains unutilized. Mola can be cultured with prawn so that it can get benefit from the vacant niche of the ponds. Besides these cultural benefits, a major advantage of prawn polyculture is that high value luxury product (Prawns) can be produced that may be exported to generate foreign exchange and simultaneously nutrient rich mola can be produced for household consumption. There is great potential of prawn-mola culture but the culture technology especially the stocking density of mola with prawn has not yet been optimized. Considering the potential of prawn-mola polyculture and the need for optimization of stocking density of mola, this experiment was carried out to evaluate the effects of stocking density of mola on the growth, production and on pond ecology in prawn polyculture.

\section{Materials and Methods}

The experiment was conducted during August to December 2010 at the Fisheries Field Laboratory, Bangladesh Agricultural University, Mymensingh for a period of 120-days in 9 rectangular earthen ponds (6 pond of $100 \mathrm{~m}^{2}$ each and 3 pond of $140 \mathrm{~m}^{2}$ each) with an average depth of $1.2 \mathrm{~m}$. The trial was conducted in a completely randomized design into three different treatments with three replications each. Stocking density of prawn (Macrobrachium rosenbergii) was same in all treatments but was different in case of mola as shown in the Table 1. 
Table 1. Experimental design

\begin{tabular}{|l|c|c|c|}
\hline \multirow{2}{*}{ Species } & \multicolumn{3}{|c|}{ Stocking density $\mathrm{m}^{-2}$} \\
\cline { 2 - 4 } & $\begin{array}{c}\text { Treatment-1 } \\
\left(\mathrm{T}_{1}\right)\end{array}$ & $\begin{array}{c}\text { Treatment-2 } \\
\left(\mathrm{T}_{2}\right)\end{array}$ & $\begin{array}{c}\text { Treatment-3 } \\
\left(\mathrm{T}_{3}\right)\end{array}$ \\
\hline Prawn (Macrobrachium rosenbergii) & 3 & 3 & 3 \\
\hline Mola (Amblypharyngodon mola) & 1 & 1.5 & 2 \\
\hline
\end{tabular}

Unwanted fishes and other aquatic organisms were eradicated by rotenone application at the rate of $30 \mathrm{~g}$ $\operatorname{dec}^{-1} \mathrm{ft}^{-1}\left(1 \mathrm{dec} .=40 \mathrm{~m}^{2}\right)$. The dead fishes and other aquatic organisms were removed by repeated netting. After one week of rotenone application, quicklime $\left(\mathrm{CaCO}_{3}\right)$ at a rate of $250 \mathrm{~kg} \mathrm{ha}^{-1}$ was liquefied into an earthen pot and then applied by spreading homogenously in the ponds. The next day after liming, the ponds were filled with water from adjacent deep tube well. All ponds were fertilized with urea and triple super phosphate (TSP) at the rates of $50 \mathrm{~kg} \mathrm{ha}^{-1}$. The PL of Prawn (Macrobrachium rosenbergii) was purchased from a commercial hatchery in Fulpur village of Mymensingh district. Feeds were prepared using local pellet machine with following ingredients: Fish meal 15\%, Mustard oil cake 20\%, Soybean meal 20\%, Rice bran 20\%, Maize flour 20\%, Molasses $4 \%$, Vitamin-mineral premix $1 \%$. Formulated feeds were applied at $10 \%$ body weight at $1^{\text {st }}$ month (upto 30 days) and reduced to $7 \%$ at $2^{\text {nd }}$ month and $5 \%$ up to the end of the experiment. Transparency, water temperature, $\mathrm{pH}$ and dissolved oxygen were measured every week at morning $(10 \mathrm{am})$ and evening $(4 \mathrm{pm})$. Ammonia-nitrogen, Nitratenitrogen, Phosphate-phosphorous and Chlorophyll-a were measured monthly. Sampling of fish weight by a digital electronic balance (Denver-XP-3000) was done monthly using a cast net to observe the growth of prawn and mola.

For the statistical analysis of the data, one-way ANOVA (Analysis of Variance) was done by using the SPSS (Statistical Package for Social Science) version-11.5 Significance was assigned at the $0.05 \%$ level.

\section{Results and Discussion}

\section{Water quality parameters}

In fish culture, water quality is usually defined as the suitability of water for the survival and growth of fish. Mean values of water quality parameters from different treatments are shown in Table 2. The mean values of water temperature were more or less close to the $27^{\circ} \mathrm{C}$ in each treatment. The recommended suitable temperature range for prawn culture is $21.9^{\circ} \mathrm{C}$ to $33.5^{\circ} \mathrm{C}$ (Fair and Foftner, 1981). Significantly higher transparency was found in $\mathrm{T}_{3}$ where mola was stocked at higher density at 2 mola $\mathrm{m}^{-2}$. It might be due to the higher grazing pressure of mola. The range of dissolved oxygen was found $6.38 \pm 1.04,6.17 \pm$ 1.35 and $6.14 \pm 1.04 \mathrm{mg} \mathrm{I}^{-1}$ in treatments $T_{1}, T_{2}$ and $T_{3}$, respectively which is good for fish and prawn culture during the research period. $\mathrm{pH}$ is considered as an important factor in freshwater prawn culture and treated as the productivity index of a water body. $\mathrm{pH}$ level of ponds water under different treatments were approximately neutral. The mean values of $\mathrm{pH}$ were $7.63 \pm 0.24,7.58 \pm 0.24$ and $7.60 \pm 0.21$ in treatments $T_{1}, T_{2}$ and $T_{3}$, respectively. The $\mathrm{pH}$ ranged from 6.8 to 8.4 was suitable for $M$ rosenbergii culture (Hossain et al., 2000).

Chlorophyll-a $\left(\mu \mathrm{g} \mathrm{I}^{-1}\right)$ value is the indicator of pond productivity, which shows an inverse relationship with water transparency (Ahmed, 1993). The mean ( \pm SD) values of chlorophyll-a were $143.51 \pm 45.58 \mathrm{\mu g} \mathrm{I}^{-1}$, $118.60 \pm 40.15 \mathrm{~g} \mathrm{I}^{-1}$ and $102.10 \pm 50.10 \mu \mathrm{g} \mathrm{I}^{-1}$ in treatments $\mathrm{T}_{1}, \mathrm{~T}_{2}$ and $\mathrm{T}_{3}$, respectively. Chlorophyll-a was significantly higher in $T_{1}$ and significantly lower in $T_{3}$. Stocking density of mola was lowest in $T_{1}$, so mola could not consume much phytoplankton as a result, Chlorophyll-a was significantly higher and transparency was significantly lower. 
Table 2. Mean values of water quality parameters (mean \pm SD) recorded from different treatments

\begin{tabular}{|c|c|c|c|c|}
\hline \multirow{2}{*}{ Parameters } & \multicolumn{3}{|c|}{ Treatments } & \multirow{2}{*}{$\begin{array}{c}\text { Level of } \\
\text { significance }\end{array}$} \\
\hline & $\mathrm{T}_{1}$ & $\mathrm{~T}_{2}$ & $\mathrm{~T}_{3}$ & \\
\hline Temperature $\left({ }^{\circ} \mathrm{C}\right)$ & $26.56 \pm 1.90$ & $26.64 \pm 1.89$ & $26.53 \pm 1.81$ & NS \\
\hline Transparency $(\mathrm{cm})$ & $37.42 \pm 2.27^{\mathrm{C}}$ & $46.08 \pm 2.74^{b}$ & $50.23 \pm 4.88^{\mathrm{a}}$ & * \\
\hline $\mathrm{pH}$ range & $7.63 \pm 0.24$ & $7.58 \pm 0.24$ & $7.60 \pm 0.21$ & NS \\
\hline $\mathrm{DO}\left(\mathrm{mg} \mathrm{l}^{-1}\right)$ & $6.38 \pm 1.04$ & $6.17 \pm 1.35$ & $6.14 \pm 1.04$ & NS \\
\hline Total alkalinity & $76.54 \pm 11.82$ & $78.85 \pm 13.41$ & $75.60 \pm 14.68$ & NS \\
\hline $\mathrm{NH}_{3}-\mathrm{N}\left(\mathrm{mg} \mathrm{l}^{-1}\right)$ & $0.23 \pm 0.25$ & $0.27 \pm 0.21$ & $0.18 \pm 0.16$ & NS \\
\hline $\mathrm{NO}_{3}-\mathrm{N}\left(\mathrm{mg} \mathrm{l}^{-1}\right)$ & $0.04 \pm 0.04$ & $0.02 \pm 0.02$ & $0.02 \pm 0.02$ & NS \\
\hline $\mathrm{PO}_{4}-\mathrm{P}\left(\mathrm{mg} \mathrm{l}^{-1}\right)$ & $0.33 \pm 0.32$ & $0.20 \pm 0.17$ & $0.31 \pm 0.29$ & NS \\
\hline Chlorophyll a $\left(\mu \mathrm{g} \mathrm{I}^{-1}\right)$ & $143.51 \pm 45.58^{a}$ & $118.60 \pm 40.15^{\mathrm{ab}}$ & $102.10 \pm 50.10^{b}$ & * \\
\hline
\end{tabular}

NS= Means are not significantly different $(P>0.05)$

* Mean values with different superscript letters in the same row indicate a significant difference at $5 \%$ significance level

The mean values of $\mathrm{NH}_{3}-\mathrm{N}$ were $0.23 \pm 0.25,0.27 \pm 0.21$ and $0.18 \pm 0.16 \mathrm{mg} \mathrm{I}^{-1}$ in treatments $\mathrm{T}_{1}, \mathrm{~T}_{2}$ and $\mathrm{T}_{3}$, respectively which were more or less similar to (Rahman ,2005) and (Asaduzzaman et al.,2006) who recorded ammonia-nitrogen value ranged from 0.01 to 0.82 and 0.203 to $0.569 \mathrm{mg} \mathrm{l}^{-1}$, respectively. The mean $( \pm S D)$ values of $\mathrm{NO}_{3}-\mathrm{N}$ were $0.04 \pm 0.04,0.02 \pm 0.02$ and $0.02 \pm 0.02 \mathrm{mg} \mathrm{l}^{-1}$ in treatments $\mathrm{T}_{1}, \mathrm{~T}_{2}$ and $\mathrm{T}_{3}$ respectively. The range of $\mathrm{NO}_{3}-\mathrm{N}$ from $0.20-3.0 \mathrm{mg} \mathrm{l}^{-1}$ were found in pond waters by (Dewan et al., 1991). The mean $( \pm S D)$ values of $P_{4}-P$ were $0.33 \pm 0.32,0.20 \pm 0.17$ and $0.31 \pm 0.29 \mathrm{mgl}^{-1}$ in treatments $T_{1}, T_{2}$ and $T_{3}$, respectively, which were more or less similar with the findings of (Wahab et al.,1995) who found phosphate-phosphorus range from $0.09 \mathrm{mg} \mathrm{l}^{-1}$ to $5.2 \mathrm{mg} \mathrm{l}^{-1}$.

\section{Plankton production}

Four group of phytoplankton: Bacillariophyceae (10 genera), Chlorophyceae (21 genera), Cyanophyceae ( 7 genera) and Euglenophyceae ( 2 genera) were found. Chlorophyceae was the most dominant group in terms of number of genera and abundance among phytoplankton in each treatment. Seventeen genera of zooplankton, including five genera of Rotifera and nine genera of Crustacea were also identified. The mean values of total plankton population were $152.97 \pm 41.71,112.63 \pm 27.31$ and $90.8 \pm 40.16$ in treatments $T_{1}, T_{2}$ and $T_{3}$, respectively. Stocking density of mola was lowest in $T_{1}$ so mola could not consume much plankton as a result mean abundance of plankton was highest in $\mathrm{T}_{1}$.

\section{Production performance of Prawn and Mola}

Mean harvesting weight of freshwater prawn were $30.00 \pm 2.00,29.00 \pm 2.65$ and $30.00 \pm 1.00 \mathrm{~g}$ in the treatments $T_{1}, T_{2}$ and $T_{3}$, respectively. In all cases, prawn growth did not differ significantly. Sadek and Moreau (1998) observed mean harvest weight of prawn 48.4-55.9 g in monoculture and $30.3 \mathrm{~g}$ in polyculture, which was more or less similar to growth recorded in the present study. So, it proves no vigorous competition between mola and prawn. Mean harvest weight and weight gain of mola were relatively higher in the treatment $T_{1}$ but did not differ significantly.

The mean survival of prawn were $59.76 \pm 1.33,59.48 \pm 2.77$ and $64.78 \pm 2.87 \%$ in treatments $T_{1}, T_{2}$ and $T_{3}$, respectively. The statistical analysis showed that the survival of prawn were significantly higher $(\mathrm{P}<0.05)$ in the treatment $T_{3}$, where mola was stocked at the density of $2 \mathrm{~m}^{-2}$. Kumar et al.(2000), Hossain et al. (2000) and Tidwell et al. (1998) reported that the survival rate of $M$ Rosenbergii monoculture was $62.4 \%$, $46.6 \%$ to $66.6 \%$ and $59 \%$, which was more or less similar to the present study. Survival depends on several factors such as competition, cannibalism and other factors. This variation might be due to association of cannibalism, death during molting and competition. Survival of mola was not measured, because mola bred after stocking, therefore, harvesting number was much higher than stocking. 
Table 3. Growth performance (mean \pm SD) of prawn and mola in three treatments

\begin{tabular}{|c|c|c|c|c|}
\hline \multirow{2}{*}{ Species } & \multicolumn{3}{|c|}{ Treatments } & \multirow[t]{2}{*}{$\begin{array}{c}\text { Level of } \\
\text { significance }\end{array}$} \\
\hline & $\mathrm{T}_{1}$ & $\mathrm{~T}_{2}$ & $\mathrm{~T}_{3}$ & \\
\hline \multicolumn{5}{|l|}{ Macrobrachium rosenbergii } \\
\hline Mean stocking weight (g) & $1.75 \pm 0.00$ & $1.75 \pm 0.00$ & $1.75 \pm 0.00$ & NS \\
\hline Mean harvesting weight(g) & $30.00 \pm 2.00$ & $29.00 \pm 2.65$ & $30.00 \pm 1.00$ & NS \\
\hline Mean weight gain $(\mathrm{g})$ & $28.25 \pm 2.00$ & $27.25 \pm 2.65$ & $28.25 \pm 1.00$ & NS \\
\hline Survival (\%) & $59.76 \pm 1.33^{b}$ & $59.48 \pm 2.77^{b}$ & $64.78 \pm 2.87^{\mathrm{a}}$ & * \\
\hline SGR (\% body weight) & $2.10 \pm 0.05$ & $2.08 \pm 0.07$ & $2.10 \pm 0.02$ & NS \\
\hline Gross production $\left(\mathrm{kg} \mathrm{h}^{-1}\right)$ & $538.05 \pm 42.12$ & $518.86 \pm 71.99$ & $583.20 \pm 37.84$ & NS \\
\hline Net production $\left(\mathrm{kg} \mathrm{h}^{-1}\right)$ & $506.67 \pm 41.70$ & $487.63 \pm 70.56$ & $549.19 \pm 36.53$ & NS \\
\hline \multicolumn{5}{|l|}{ Amblypharyngodon mola } \\
\hline Mean stocking weight (g) & $0.08 \pm 0.00$ & $0.08 \pm 0.00$ & $0.08 \pm 0.00$ & NS \\
\hline Mean harvesting weight (g) & $3.567 \pm 0.71$ & $2.767 \pm 0.49$ & $2.800 \pm 0.20$ & NS \\
\hline Mean weight gain $(\mathrm{g})$ & $2.77 \pm 0.71$ & $1.97 \pm 0.49$ & $2.00 \pm 0.20$ & NS \\
\hline Gross production $\left(\mathrm{kg} \mathrm{h}^{-1}\right)$ & $32.39 \pm 5.93$ & $38.18 \pm 8.97$ & $35.56 \pm 4.46$ & NS \\
\hline Net production $\left(\mathrm{kg} \mathrm{h}^{-1}\right)$ & $24.98 \pm 5.27$ & $27.12 \pm 8.06$ & $25.42 \pm 3.84$ & NS \\
\hline \multicolumn{5}{|l|}{ Prawn and mola combined } \\
\hline Gross production $\left(\mathrm{kg} \mathrm{h}^{-1}\right)$ & $570.44 \pm 41.34$ & $557.04 \pm 80.65$ & $618.76 \pm 41.25$ & NS \\
\hline Net production $\left(\mathrm{kg} \mathrm{h}^{-1}\right)$ & $531.65 \pm 42.40$ & $514.75 \pm 77.91$ & $574.61 \pm 39.58$ & NS \\
\hline
\end{tabular}

The mean net production of prawn were $506.67 \pm 41.70,487.63 \pm 70.56$ and $549.19 \pm 36.53 \mathrm{~kg} \mathrm{ha}^{-1}$ in treatments $T_{1}, T_{2}$ and $T_{3}$, respectively. The yield of prawn in the present study lied within the yield ranges 95 to $1297 \mathrm{~kg} \mathrm{ha}^{-1}$ in monoculture recorded by Kurup and Ranjeet (2002). Haroon and Alam (1992) observed the production of prawn as $220 \mathrm{~kg} \mathrm{ha}^{-1}$ in rice field for 160 days culture period, which is less than the production in this study.

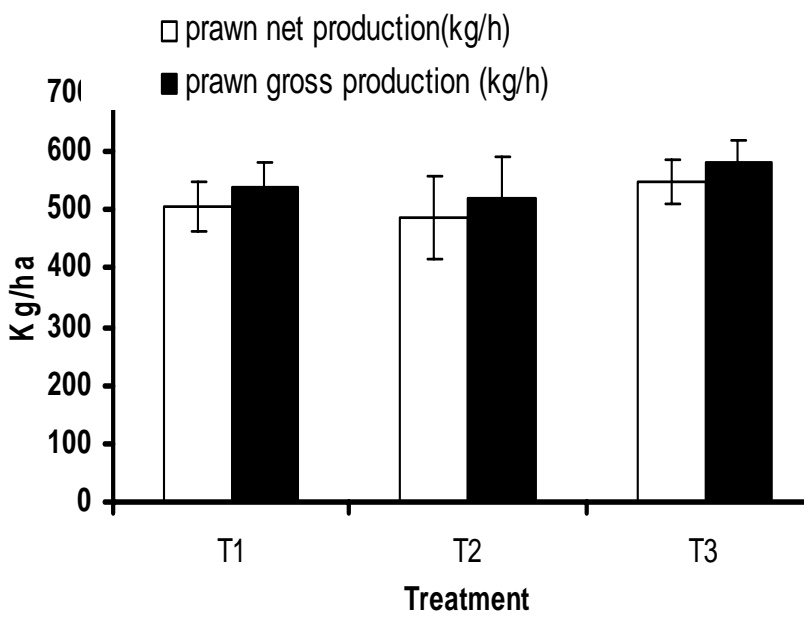

Fig. 1. Net and gross production of mola among three treatments

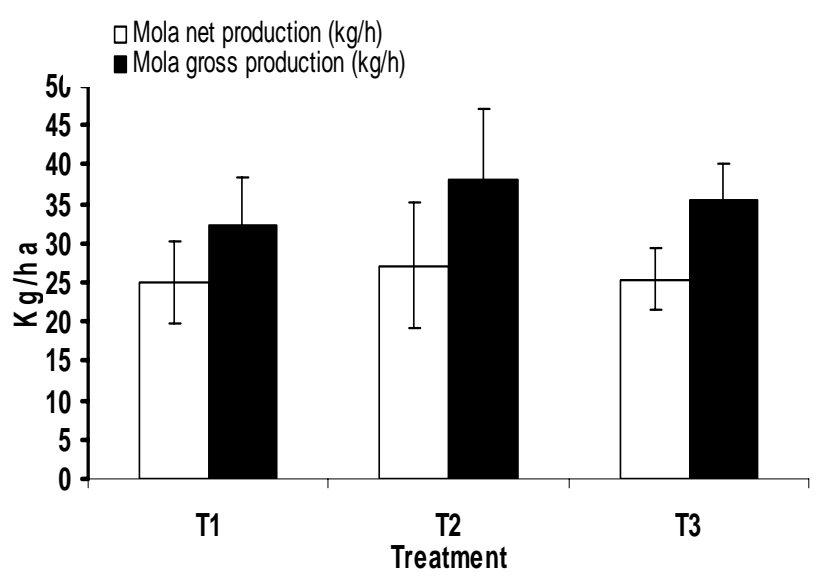

Fig. 2. Net and gross production of prawn among three treatments 
The mean net productions of mola were $24.98 \pm 5.27,27.12 \pm 8.06$, and $25.42 \pm 3.84$ in treatments $T_{1}, T_{2}$ and $\mathrm{T}_{3}$, respectively. Productions of mola were similar in all treatments, which indicated that there were no effects of prawn on the growth of mola. Yield of mola recorded by Chowdhury et al. (2000) was 7.92-12.5 $\mathrm{kg} \mathrm{ha}^{-1}$ in polyculture with carp, which was lower than the yield obtained in the present study. Significantly higher survival of prawn was found in the treatment $T_{3}$. The gross and net production of prawn observed was relatively higher in $T_{3}$, where mola was stocked at a density of $2 \mathrm{~m}^{-2}$. The highest combined gross and net production of mola and prawn was found in the same treatment, which indicated there were no negative impacts of mola on freshwater prawn.

\section{Conclusion}

Growth and production performance showed that the highest gross and net production of prawn was recorded in $T_{3}$. The combined gross and net production of prawn and mola was also highest in the same treatment. It might be concluded that there were no effects of addition of mola on prawn production, and $\mathrm{T}_{3}$ is the best proposition for prawn-mola polyculture, in which prawn can be cash crop and mola can be consumed at household levels.

\section{References}

Ahmed, Z.F. 1993. Electivity index and dietary overlap of Catla catla (Hamilton) in fertilized ponds of Bangladesh. M.S. dissertation, Dept. of Fisheries Biology and Limnology, Bangladesh Agricultural University, Mymensingh, 163 p.

Asaduzzaman, M., Yang, Y., Wahab, M.A., Diana, J.S. and Ahmed, Z.F. 2006. Farming system of giant freshwater prawn Macrobrachium rosenbergii in Bangladesh: a combination of tradition and technology. Proceeding of the WAS conference (AQUA 2006) held on 9-13 May, 2006 in Florence, Italy.

Chowdhury, M.T.H.,Dewan, S., Wahab, M.A.,Uddin, M.J. and Thilsted S.H. 2000. Water quality parameters of the rice fields used for rice cum fish culture. Bangladesh J. Fish., 23 (1): 25-29

Dewan, S.,Wahab, M.A., Beveridge, M.C.M., Rahman M.H. and Sarker B.K. 1991. Food selection, electivity and dietary overlap among planktivorous Chinese and Indian major carp fry, fingerlings grown in extensively managed, rainfed ponds in Bangladesh. Aquaculture and Fisheries Management, 22: 1188-1190.

DoF. 2011. Department of Fisheries, Ministry of Fisheries and Livestock. National Fishery Week 2011.20-26 July. pp. 118-123.

Fair, P.H. and Foftner, A.R. 1981. The role of formulated feeds on natural productivity in culture of the prawn, Macrobrachium rosenbergii. Aquaculture, 24: 233-243.

Haroon, A.K.Y. and Alam, M. 1992. Experimental study on Paddy-cum-fish/shrimp farming in Bangladesh. Effect of fertilizers on growth and yield. Bangladesh J. Zool., 13: 25-28

Hossain, M.A., Siddique, M.A.L. and Miaje, M.A.H. 2000. Development of low-cost feed for culture of giant freshwater prawn (Macrobrachium rosenbergii de Man) in ponds. Bangladesh J. Fish. Res., 4(2): 127-134.

Kumar, J.S.S., Nagamuthu, N., Velliah, S., Nagarathinam, N. and Sundararaj, V. 2000. Production characteristics of Macrobrachium rosenbergii and M. malcolmsonii under controlled monoculture system. J. Aquacult. Trop., 15 (3): 121-126

Kurup, B.M. and Ranjeet, K. 2002. Integration of Freshwater Prawn culture with rice farming in Kuttanad, India. NAGA, 25 (3-4): 1619.

Rahman, M.A. 2005. Production performance of overwintering juveniles of giant freshwater prawn, Macrobrachium rosenbergii under monosex and mixed sex culture systems. M.S. dissertation, Dept. of Fisheries Management, Bangladesh Agricultural University, Mymensingh. $95 \mathrm{p}$.

Sadek, S. and Moreau, J. 1998. Culture of Macrobrachium rosenbergii in monoculture and polyculture with Oreochromis niloticus in paddies in Egypt. Bamidgeh, 50 (1): 33-42.

Thilsted, S.H., Roos, N. and Hasan, N. 1997. The role of small indigenous fish species in food and nutrition security in Bangladesh. NAGA- The ICLARM Quarterly, July-Dec.: 13-15.

Tidwell, J.H., Coyle, S.D. and Schulmeister, G. 1998. Effects of added substrate on the production and population characteristics of freshwater prawns Macrobrachium rosenbergii in ponds. J. World Aquacult. Soc., 29 (1): 17-22

Wahab, M.A., Ahmed, Z.F., Islam, A. and Rahmatullah, S.M.1995. Effect of common carp, Cyprinus carpio (L) on the pond ecology and growth of fish in polyculture. Aquacult. Res., 26: 619-928. 